\title{
MEDICINE
}

\section{THE STATE OF HYGIENE AND LOCAL IMMUNITY OF THE ORAL CAVITY IN PATIENTS WITH ANOREXIA NERVOSA}

\author{
${ }^{1}$ Doctor of Medicine, Professor M. Yu. Antonenko, \\ ${ }^{l}$ L. L. Reshetnyk, \\ ${ }^{2}$ E. V. Moskalenko, \\ ${ }^{I} \mathrm{PhD}$, associate professor N. A. Zelinska, \\ ${ }^{I}$ PhD, associate professor $\boldsymbol{O}$. A. Znachkova \\ ${ }^{1}$ Ukraine, Bogomolets National Medical University, Department of Dentistry \\ ${ }^{2}$ Ukraine, Kiev Clinical Hospital on railway transport №1 «Ukrzaliznytsya»
}

DOI: https://doi.org/10.31435/rsglobal_wos/28022019/6340

\section{ARTICLE INFO}

Received: 11 December 2018

Accepted: 21 February 2019

Published: 28 February 2019

\section{KEYWORDS}

generalized periodontitis, anorexia nervosa, oral hygiene indices, secretory immunoglobulin, serum immunoglobulin. \begin{abstract}
Aim: to study the state of local immunity and oral hygiene in patients with GP suffering from AN.

Materials and methods: 35 patients with AN were examined at the age of 19-35 years. In the study we used immunological methods, an index assessment of the state of oral hygiene (PMA, API, GI).

Results and discussion: in patients of I group poor oral hygiene was established. The amount of lysozyme in the oral fluid in I group was $0.014 \pm 0.07 \mathrm{~g} / \mathrm{l}$. A decrease SIgA (11SIgA) was established in patients of I group: I, II and control $(135.31 \pm 23.17,130.26 \pm 24.21$ and 300.34 $\pm 27.38 \mathrm{mg} / \mathrm{l}$, respectively). A tendency to an increase in the level of IgG in the oral fluid in patients of group II compared with I and the control group $(5.35 \pm 0.36$, vs. $4.57 \pm 0.04$ and $4.98 \pm 0.23 \mathrm{~g} / \mathrm{l}$, respectively) was established.

Conclusions: poor oral hygiene is an objective indicator which reflects low motivation to maintain oral health. The observed immunodeficiency (11SIgA) in patients with GP is a mirror image of changes occurring in the body of patients with AN.
\end{abstract}

Citation: M. Yu. Antonenko, L. L. Reshetnyk, E. V. Moskalenko, N. A. Zelinska, O. A. Znachkova. (2019) The State of Hygiene and Local Immunity of the Oral Cavity in Patients with Anorexia Nervosa. International Academy Journal Web of Scholar. 2(32). doi: 10.31435/rsglobal_wos/28022019/6340

Copyright: (C) 2019 M. Yu. Antonenko, L. L. Reshetnyk, E. V. Moskalenko, N. A. Zelinska, O. A. Znachkova. This is an open-access article distributed under the terms of the Creative Commons Attribution License (CC BY). The use, distribution or reproduction in other forums is permitted, provided the original author(s) or licensor are credited and that the original publication in this journal is cited, in accordance with accepted academic practice. No use, distribution or reproduction is permitted which does not comply with these terms.

Diseases of periodontal tissues, including generalized periodontitis (GP), occupy one of the key positions in the structure of dental diseases [3]. In recent years, their prevalence has increased significantly and, according to a number of researchers, has reached 57-80\%. This circumstance causes serious concern of state, scientific and medical institutions [6].

Manifest halitosis, bleeding and unaesthetic view of periodontal soft tissues, destruction of the alveolar outgrowth, the arising mobility and loss of teeth significantly impair the quality of life of patients. Microorganisms of periodontal pockets often cause an immune conflict, bringing to the sensitization and allergization of the body, cause the launch of an autoimmune component that 
supports the pathological process not only in the periodontal complex, but also in the body of a patient.

One of the dominant factors that potentiate the development of generalized periodontal diseases, including GP, is a disease of internal organs and systems. Among it, an important role is assigned to diseases of the intestine, stomach, musculo-skeletal system, endocrine and hormonal diseases. $[1,2]$. The latter, according to many researchers, causes a contravention in the bone tissue metabolism of the alveolar outgrowth, leading to a mismatch of remodeling processes with a predominance of osteoresorption over bone formation processes [6].

The pathological process in the alveolar ridge changes the structure and then the shape of the bone, up to its complete resorption. Androgens and estrogens, which regulate protein-calcium metabolism, are considered to be one of the leading factors influencing bone tissue remodeling processes. The level of the latter undergoes significant changes in a number of conditions and diseases, including, anorexia nervosa (AN).

In recent years, AN occupies a significant place in the structure of human diseases. According to the WHO, the prevalence of this disease is $0.9-4.3 \%[1,2,4]$. It has been established that AN is caused by organic and functional disorders of the centers at the level of the hypothalamus and higher analyzers of the cerebral cortex. Most often, AN accompanies organic diseases of the endocrine glands and is an important symptom of pituitary cachexia and adrenal insufficiency. This disease develops as a result of a special reaction to various adverse effects of both exogenous and endogenous nature. Among which a key role is given to foci of chronic infection, including in the oral cavity. According to a number of researchers, during long-term existence, AN poses a great threat to the organism, causing imbalance in the work of all components of immunological reactivity $[8,9,10]$. We suppose that a major omission was the insufficient attention paid to the study of AN and GP in the light of a possible associative link, as well as outside the context of assessing indicative features of the state of oral hygiene in this category of patients.

Objective of the research: to study the format of the state of local immunity and oral hygiene in patients with GP suffering from anorexia nervosa.

Materials and methods. To achieve this goal, clinical, radiological and immunological methods were used, as well as an index assessment of oral hygiene (PMA, API, GI).

The diagnosis of periodontal disease was established in accordance with the classification of N. F. Danilevskogo (1994). The diagnosis of AN was determined by the specialists of neuropsychiatric department of Kiev Clinical Hospital on railway transport №1.

The study involved 86 people $19-35$ years old.

In 35 examined patients with AN we diagnosed generalized periodontitis of the primary-I degree of the chronic course (main group).

The results of the research we compared with 21 patients who had GP primary-I degree chronic course with no complications of AN (comparative group).

The results of a study were the research of 30 mentally healthy people of similar age who had a mass deficit reaching 15\% in accordance with the body mass index - the control group. In this group dental diseases as well as diseases of internal organs and systems were excluded.

To determine the state of the secretory immunoglobulin SIgA (11SIgA), the generally accepted method of radial immunodiffusion in the gel according to G. Mancini (1964) was applied.

Determination of serum immunoglobulins 7SIgA, IgM, IgG in the oral fluid was determined in the reaction of G. Mancini (1964), modified by the tissue culture laboratory of the State Institute of Hematology and Transfusion of the Academy of Medical Sciences of Ukraine.

Determination of oral fluid lysozyme was carried out according to the generally accepted scheme of G. Sinai and O. Berger in the modification of the laboratory of microbiology of the State Institute of Hematology and Transfusion of the National Academy of Medical Sciences of Ukraine. To determine the concentration of oral lysozyme, a 24-hour agar test culture of Micrococcus Lysoclastscus (M.L.) strain No. 2665 was used.

Statistical methods STATISTICA 6.0 were used, $<0.05$ were considered reliable features.

The results of the research and their discussion.

In an index assessment of the level of oral hygiene in patients with GP of primary-I degree of chronic course with AN poor oral hygiene was established in both the main and comparative groups. However, it should be noted that in the main group (patients with GP of initial-I degree, burdened with 
AN), these indicators were significantly higher (table 1). An unsatisfied level of hygiene was observed in all patients of the main group, while in the comparative group (patients with GP initial-I degree chronic course, not burdened with $\mathrm{AN}$ ) were observed less frequently (73.2 $\pm 1.2 \%$ of cases).

Table 1. Index assessment of the oral cavity in patients with generalized periodontitis of the initial-I degree of chronic course, suffering from anorexia nervosa.

\begin{tabular}{|l|c|c|c|}
\hline \multicolumn{2}{|c|}{ Groups of examined patients } & \multicolumn{3}{|c|}{ Indices } \\
\cline { 2 - 4 } & PMA & API & GI \\
\hline $\begin{array}{l}\text { AN+GP initial-I degree of chronic course (main } \\
\text { I) }\end{array}$ & $0,4250,024$ & $0,581 \pm 0,026$ & $1,641 \pm 0,09$ \\
\hline $\begin{array}{l}\text { GP of initial-I degree of chronic course } \\
\text { (comparative II) }\end{array}$ & $0,324 \pm 0,022$ & $0,474 \pm 0,029$ & $1,326 \pm 0,08$ \\
\hline Control & $0,08 \pm 0,03$ & $0,09 \pm 0,02$ & $0,301 \pm 0,01$ \\
\hline
\end{tabular}

In the control group the overwhelming number of patients a satisfactory state of oral hygiene was found. Only in 5\% of those examined we observed an unsatisfactory state of oral hygiene.

We recorded low levels of lysozyme oral fluid in patients of the main group (table 2).

Table 2. Indicators of lysozyme in the oral fluid in patients with generalized periodontitis, burdened with anorexia nervosa

\begin{tabular}{|l|c|c|}
\hline \multicolumn{1}{|c|}{ Groups of examined patients } & $\begin{array}{c}\text { The number of } \\
\text { examined }\end{array}$ & $\begin{array}{c}\text { The number of } \\
\text { lysozyme g/ } 1 \\
\text { (M } \pm \text { m) }\end{array}$ \\
\hline $\begin{array}{l}\text { I main } \\
\text { (AN + GP initial-I degree of chronic course) }\end{array}$ & 35 & $0,014 \pm 0,07$ \\
\hline $\begin{array}{l}\text { II comparative } \\
\text { (GP of initial-I degree of chronic course) }\end{array}$ & 21 & $0,03 \pm 0,04$ \\
\hline Control & 30 & $0,06 \pm 0,004$ \\
\hline
\end{tabular}

Thus, the amount of lysozyme in the oral fluid in this group was $0.014 \pm 0.07$. In the comparative group this indicator, although it was higher and was $0.03 \pm 0.004 \mathrm{~g} / \mathrm{l}$, nevertheless, was significantly lower than in the control group.

While investigating the state of secretory immunity in patients with GP of the initial-I degree of the chronic course, assosiated with AN, significant changes were found because of decreasing SIgA (11SIgA) in patients of the main group compared to the comparative and control groups (135.31 \pm $23.17,130.26 \pm 24.21$ and $300.34 \pm 27.38 \mathrm{mg} / \mathrm{l}$, respectively), which indicates a pronounced immunodeficiency key of local immunity (table 3 ).

Table 3. The concentration of secretory immunoglobulin SIgA (11SIgA) in the oral fluid in patients with generalized periodontitis, assosiated with anorexia nervosa.

\begin{tabular}{|l|c|c|}
\hline \multicolumn{1}{|c|}{ Groups of examined patients } & $\begin{array}{c}\text { The number of } \\
\text { examined }\end{array}$ & $\begin{array}{c}\text { The number of SIgA } \\
\mathrm{mg} / 1(\mathrm{M} \pm \mathrm{m})\end{array}$ \\
\hline $\begin{array}{l}\text { I main } \\
\text { (AN +GP initial-I degree of chronic course) }\end{array}$ & 35 & $135,31 \pm 23,17$ \\
\hline $\begin{array}{l}\text { II comparative } \\
\text { (GP of initial-I degree of chronic course) }\end{array}$ & 21 & $130,26 \pm 24,21$ \\
\hline Control & 30 & $300,34 \pm 27,38$ \\
\hline
\end{tabular}

While determining the indicators of serum $\operatorname{IgA}(7 \mathrm{SIgA})$ in the oral fluid a significant decrease in the amount of $\operatorname{IgA}(7 \mathrm{SIgA})$ was found in patients with GP of the initial-I degree of the chronic course, suffering from AN (table 4). 
Table 4. The composition of serum immunoglobulin IgA (7SIgA), IgM, IgG in the oral fluid of patients with generalized periodontitis of the initial-I degree of the chronic course, aggravated by anorexia nervosa

\begin{tabular}{|l|c|c|c|c|}
\hline \multicolumn{1}{|c|}{ Groups of patients } & \multirow{2}{*}{$\begin{array}{c}\text { Number of } \\
\text { examined patients }\end{array}$} & \multicolumn{3}{c|}{ Concentration Ig } \\
\cline { 3 - 5 } & 35 & $0,46 \pm 0,02$ & $0,62 \pm 0,03$ & $4,57 \pm 0,04$ \\
\hline $\begin{array}{l}\text { I main } \\
\text { (AN+GP initial-I degree of chronic course) }\end{array}$ & & & & \\
\hline $\begin{array}{l}\text { II comparative } \\
\text { (GP of initial-I degree of chronic course) }\end{array}$ & 21 & $0,93 \pm 0,031$ & $0,81 \pm 0,02$ & $5,35 \pm 0,36$ \\
\hline Control & 30 & $1,03 \pm 0,02$ & $0,85 \pm 0,04$ & $4,98 \pm 0,23$ \\
\hline
\end{tabular}

Note that in the comparative group, although there was a slight decrease in the number of $\operatorname{IgA}$ (7SIgA), $\operatorname{IgM}$, however, the obtained data were unreliable.

A tendency to an increase in the level of $\mathrm{IgG}$ in the oral fluid in the comparative group compared with the main and control groups was established $(5.35 \pm 0.36$, vs. $4.57 \pm 0.04$ and $4.98 \pm$ $0.23 \mathrm{~g} / \mathrm{l}$, respectively).

Conclusions. 1. Poor oral hygiene according to indicative hygienic indicators (RMA, API, GI) in all patients with GP initial-I degree of chronic course, burdened with AN, could indicate that the aggressiveness of periodontal microorganisms contributes not only to aggravation and acceleration of the pathological process periodontal tissues, but also serves as a potentiating component supporting and aggravating the course of anorexia nervosa.

2. The unsatisfactory state of oral hygiene serves as an objective indicator reflecting low motivational components to maintaining oral health, as well as showing a lack of an objective understanding of the risks to their overall health.

3. We believe that the observed immunodeficiency of the main immunological link of local immunity (11SIgA) in patients with GP is a mirror image of changes occurring in the body of AN patients. On the other hand, the aggressive microflora of periodontal pockets undoubtedly has a negative impact on the manifestation of AN.

4. The conducted studies allow us to suggest an assumption that the pathogenetic mechanisms are interdependent in patients with GP associated with AN.

\section{REFERENCES}

1. Matytsina, LA, Anorexia Nervosa in Girls / L.A. Matytsina, I.V. Babenko-Sorokopud // Med.-Sots. problems family. - 2013. - V. 8, № 4. - P.120-127. [Matyitsina L.A., Nervnaya anoreksiya u devushek/ L.A.Matyitsina, I.V.Babenko-Sorokopud // Med.-sots. probl. sIm'Yi. - 2013. - T. 8, № 4. - C.120-127.] [in Ukraine].

2. Chaika V.K., Anorexia nervosa in girls and girls / V.K. Chayka, L.L. Matyschina. - Donetsk: Leader, 2004. - 156 p. [ Chayka V.K., Nervnaya anoreksiya u devochek i devushek/ V.K.Chayka, L.L. Matyischina. Donetsk: Lider, 2004. - $156 \mathrm{~s}$ ] [ in Ukraine].

3. Narisi practical parodontologii / / Ed. prof. M.Yu.Antonenko // Dovidnik likarya "Dentist", - 2-g view. - K.: TOV Library Health, Ukraine, 2017. - 348 p. [ Chayka V.K., Nervnaya anoreksiya u devochek i devushek/ V.K. Chayka, L.L. Matyischina. - Donetsk: Lider, 2004. - 156 s.] [in Ukraine].

4. Evans E.A., Abuse and misuse of antidepressants/ E.A.Evans, M.A.Sullivan // Subst. Abuse Rehabil. 2014, Aug 14. - Vol 5. - P. 107-120.

5. Fournier J.C, Antidepressant Drag Effects and Depression Severity: A Patient-Level Meta-analysis/ J.C.Fournier, R.J.Rubeis, S.D.Hollon et al // The Journal of American Medical Association. — January 6, 2010. - T. 303, № 1. - P.47-53.

6. Povoroznyuk V.V., Bone system and periodontal diseases / V.V. Povoroznyuk, I.P. Mazur // K., 2004. 446 p. [Povoroznyuk V.V., Kostnaya sistema i zabolevaniya parodonta/ V.V. Povoroznyuk, I.P. Mazur // K., 2004. - 446 s.] [ in Ukraine].

7. Hasler G., Pathophysiology of depression: do we have any solid evidence of interest to clinicians?/ G. Hasler, J.C. Fournier // World psychiatry: official journal of the World Psychiatric Association (WPA). 2010. - Vol.9, №3. - P.155-161.

8. Lambley P, How to survive anorexia// London, 2005. - P. 241- 267.

9. Wiles N., Cognitive behavioural therapy as an adjunct to pharmacotherapy for primary care based patients with treatment resistant depression: results of the CoBalT randomised controlled trial/ N. Wiles, L. Thomas, A.Abel, N.Ridgway et al // Lancet - 2013, Feb 2, - T. 381, № 9864. - P.375-384.

10. Mathewson J. J. et al // Diagn. Microbiol infect. Dis. - 1989. - Vol. 12, N 2. - P. 139-141. 